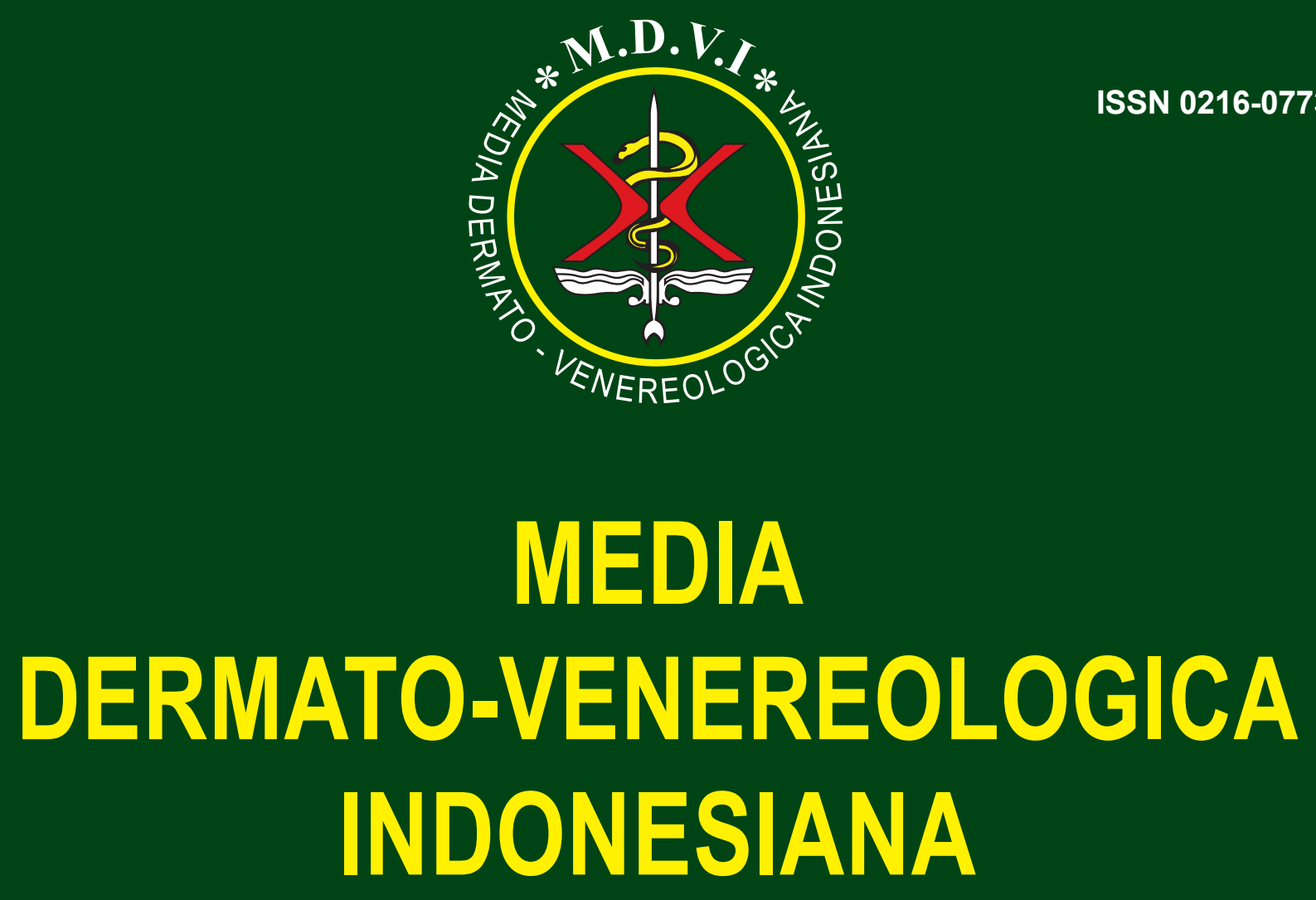

Editorial : Trias epidemiologis : Pendekatan memahami orkestra sistem imunologi kulit

Uji klinis sampo formulasi khusus pada pasien ketombe dan dermatitis seboroik ringan pada skalp

Tingkat pengetahuan dan sikap pekerja binatu terhadap dermatitis kontak

Korelasi antara kadar superoksida dismutase dengan malondialdehid pada jaringan keratosis seboroik

Psoriasis vulgaris berat diterapi mikofenolat mofetil: tantangan dalam pengobatan

Terapi dapson pada pemfigoid bulosa

Modern wound dressing pada ulkus trofik pasien kusta tipe lepromatosa

Peningkatan enzim transaminase pada kusta

Korelasi gambaran histopatologi, teknik biopsi dan manifestasi klinis vaskulitis leukositoklastik kutan

Peran mikrobiom pada infeksi menular seksual

Melasma dalam sudut pandang genetik 


\title{
KORELASI GAMBARAN HISTOPATOLOGI, TEKNIK BIOPSI, DAN MANIFESTASI KLINIS VASKULITIS LEUKOSITOKLASTIK KUTAN
}

\author{
Sekar Puspita Lilasari, * Diah Prabawati Retnani, ** M. Cholis* \\ *Departemen Dermatologi dan Venereologi, \\ **Departemen Patologi Anatomi \\ FK Universitas Brawijaya/RSUD dr. Saiful Anwar, Malang
}

\begin{abstract}
ABSTRAK
Vaskulitis kutan dapat sembuh sendiri baik terbatas pada kulit maupun merupakan bagian dari sindrom vaskulitis sistemik. Vaskulitis leukositoklastik kutan adalah vaskulitis nekrotik pada kulit terutama pada pembuluh darah kecil. Manifestasi klinis dapat berupa makula, purpura yang dapat dipalpasi, pustul, urtika, bula hemoragik, nodus, serta ulserasi. Diagnosis ditegakkan berdasarkan anamnesis riwayat penyakit, manifestasi klinis, dan biopsi kulit. Karakteristik histopatologi ditandai dengan degenerasi apoptotik pada nukleus neutrofil (leukositoklasia), nekrosis fibrinoid di dinding pembuluh darah, dan ekstravasasi eritrosit. Namun, sedikit sekali vaskulitis kutan yang menunjukkan gambaran histopatologi yang patognomonik. Pengambilan sampel biopsi yang tidak tepat waktu dan pemilihan lesi yang kurang sesuai dapat menyebabkan gambaran histopatologis tidak khas untuk vaskulitis. Selain itu, pemilihan teknik biopsi juga berdampak terhadap diagnosis vaskulitis. Pemilihan teknik biopsi dilakukan berdasarkan pembuluh darah yang akan diperiksa. Tipe pembuluh darah bergantung pada lokasi di dalam kulit dan subkutis. Agar dapat memperoleh interpretasi gambaran vaskulitis kutan yang lebih baik dibutuhkan korelasi antara gambaran histopatologi, teknik pengambilan lesi dengan manifestasi klinis.
\end{abstract}

Kata kunci: vaskulitis, leukositoklastik, histopatologi

\section{HISTOPATHOLOGICAL FEATURES, BIOPSY TECHNIQUE AND CLINICAL MANIFESTATION CORRELATION IN CUTANEOUS LEUKOCYTOCLASTIC VASCULITIS}

\begin{abstract}
Cutaneous vasculitis may be a self-limited disease restricted to the skin or a part of various systemic vasculitis syndromes. Cutaneous leukocytoclastic vasculitis is a necrotizing vasculitis in the skin that predominantly involves small vessels. It may manifest as macules, palpable purpura, pustule, urtica, hemorrhagic bullae, nodules and ulceration. Diagnosis is based on history, clinical manifestation and skin biopsy. Histopathologic features of cutaneous leukocytoclastic vasculitis are characterized by apoptotic degeneration from granulomatous of nucleus cells (leukocytoclasia), fibrinoid necrosis on the vessels walls and erythrocytes extravasation. However, cutaneous vasculitis has very few pathognomonic histological findings. Histopathological features will not appear as vasculitis unless biopsy is done at the right time and at the right skin lesion. Moreover, choosing the right biopsy technique affects the diagnosis of vasculitis. Choosing biopsy technique is based on which type of blood vessels is involved. The type of blood vessels depends on the location within the skin and subcutis. Therefore, correlation between histopathological features, biopsy technique and clinical manifestations are needed to ensure better interpretation of cutaneous vasculitis.
\end{abstract}

Keywords: vasculitis, leukocytoclastic, histopathology

Korespondensi:

J1. Jaksa Agung Suprapto No.2, Malang,

Telp. 0341-362101/085334033463

email: drsekarpuspita@gmail.com 


\section{PENDAHULUAN}

Vaskulitis adalah proses inflamasi dan nekrosis pembuluh darah, baik di vena, arteri ataupun keduanya. Keterlibatan kulit sangat sering terjadi pada berbagai tipe vaskulitis. ${ }^{1}$ Vaskulitis leukositoklastik kutan merupakan istilah histopatologi yang menunjukkan vaskulitis di pembuluh darah kecil dengan komponen utama infiltrat inflamasi berupa neutrofil. Diagnosis dan terapi vaskulitis leukositoklastik kutan merupakan sebuah tantangan karena penyakit ini merupakan gabungan dari beberapa gangguan atau penyakit. ${ }^{2}$

Diagnosis vaskulitis kutan paling baik ditegakkan dengan pemeriksaan histopatologi jaringan kulit yang mengandung pembuluh darah yang terkena serta terdapat respons inflamasi. Gambaran histopatologi sangat penting untuk membedakan vaskulitis kutan sebenarnya dengan pseudovaskulitis kutan atau dengan oklusi pembuluh darah. ${ }^{3,4}$ Sedikit sekali proses vaskulitis dengan temuan-temuan histologi yang patognomonis. ${ }^{5}$ Gambaran histopatologi pada vaskulitis leukositoklastik kutan mengalami perkembangan seiring waktu, sehingga hasil temuannya dipengaruhi oleh waktu pengambilan biopsi lesi kulit. ${ }^{2}$ Oleh karena itu, dibutuhkan kerja sama antara klinisi dan ahli dermatopatologi untuk menggabungkan temuan klinis dan histopatologi agar dapat menginterpretasikan hasil secara tepat.

Tujuan penulisan tinjauan pustaka ini adalah untuk mengetahui gambaran histopatologi vaskulitis leukositoklastik kutan serta teknik pengambilan lesi kulit berdasarkan klinisnya.

\section{Definisi dan Etiologi Vaskulitis Leukositoklastik Kutan}

Vaskulitis nekrotik kutan secara klinis dikenal sebagai vaskulitis/venulitis kutan nekrotik (VKN), vaskulitis pembuluh darah kecil kutan karena terutama terjadi di venula, ${ }^{6}$ dan vaskulitis/angiitis kutan leukositoklastik (VLK). ${ }^{4}$ VLK adalah bentuk vaskulitis kutan yang paling sering, dan mengenai pembuluh darah kecil. Tanda khas klinis VLK adalah purpura yang dapat diraba. Karakteristik histopatologi ditandai dengan infiltrasi neutrofil di sekitar dinding pembuluh darah disertai degranulasi dan apoptosis neutrofil (leukositoklasia), nekrosis fibrinoid di dinding pembuluh darah, dan ekstravasasi eritrosit. ${ }^{2}$

Etiologi penyakit yang dapat menunjukkan gambaran histopatologi vaskulitis leukositoklastik kutan adalah sebagai

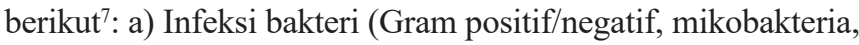
spirochaeta), Rickettsia (Rocky Mountain spotted fever; Scrub typhus), jamur, dan virus, b) Jejas imunologik yang diperantarai kompleks imun, seperti Henoch-Schonlein purpura, urticarial vasculitis, cryoglobulinemia, serum sickness, connective tissue disease, autoimmune disease c) Jejas imunologik akibat infeksi (contoh hepatitis B atau C, streptokokus, d) Drug-induced vasculitis, e) Proses paraneoplastik, f) Penyakit Behcet, g) Erythema elevatum diutinum, h) Antineutrophil-antibody associated, i) Granulomatosis Wegener, j) Microscopic polyangitis, k) Churg-Strauss syndrome, 1) idiopatik, dan m) poliarteritis nodosa.

\section{Patogenesis Vaskulitis Kutan Leukositoklastik}

Vaskulitis leukositoklastik kutan disebabkan oleh deposit kompleks imun dalam venula post-capillary. Kompleks imun yang berada dalam sirkulasi terdiri atas antigen dan antibodi ( $\operatorname{IgG}$, IgA, dan IgM). Ukuran dan kelarutan kompleks imun tersebut, akan menyebabkan berikatan dengan endotel pembuluh darah kecil. Bila antigen berlebih, maka akan terbentuk kompleks imun yang sulit dibersihkan dari sirkulasi, menjadi tidak larut, sehingga terdeposit di pembuluh darah kecil. $^{2,8}$

Deposit kompleks imun mengaktivasi kaskade komplemen sehingga terbentuk faktor kemotaktik C3a dan C5a yang secara langsung merekrut neutrofil, basofil, dan sel mast ke tempat jejas. Faktor C5a dan sinyal inflamasi lainnya pada vaskulitis leukositoklastik kutan (thrombin, IL-1, TNF- $\alpha$ ) juga menyebabkan peningkatan molekul adhesi (selektin, integrin, dan anggota dari superfamili imunoglobulin) di sel endotel dan leukosit. Upregulation molekul adhesi akan membantu perekrutan sel inflamasi dari sirkulasi, membantu penarikan, dan mempermudah migrasi ke tempat inflamasi. ${ }^{2,8}$

Kerusakan jaringan akan mengaktifkan sinyal bahaya, sehingga menyebabkan pelepasan sitokin tambahan (misal IL8). Interleukin-8 selanjutnya akan membantu migrasi neutrofil. Sel polimorfonuklear (PMN) yang direkrut akan mengalami degranulasi, melepaskan enzim proteolitik dan radikal bebas, selanjutnya akan menyebabkan kerusakan dinding pembuluh darah. Basofil dan sel mast yang direkrut akan membantu pelepasan histamin, dan meningkatkan permeabilitas vaskular. Kerusakan dan kebocoran pembuluh darah mempermudah deposit kompleks imun dan sel inflamasi sehingga terjadi pengulangan siklus inflamasi. ${ }^{8}$

Karakteristik vaskulitis leukositoklastik adalah infiltrasi dan akumulasi sel apoptotik yang menetap atau neutrofil nekrotik atau fragmen nuklei dari neutrofil pada jaringan di sekitar pembuluh darah (leukositoklasia), dan edema endotel disertai dengan nekrosis fibrinoid di dinding pembuluh darah. Fenomena leukositoklasia ini sangat menarik, oleh karena secara normal, sel mati akan cepat ditangkap oleh makrofag untuk difagosit, terutama di tempat inflamasi. Oleh karena itu, akibat akumulasi sel-sel mati dan debris nuklear di lesi tersebut diduga terjadi pembersihan (klirens) sel apoptotik atau nekrotik yang tidak sempurna. ${ }^{8}$

Vaskulitis leukositoklastik kutan sebelumnya telah diketahui bahwa diperantarai oleh sel PMN saja, tetapi ternyata limfosit juga direkrut terutama pada penyakit yang berlangsung lama. Limfosit kemungkinan bereaksi dengan autoantigen yang dipaparkan oleh kerusakan jaringan dan berperan penting dalam aktivitas penyakit kronis. ${ }^{8}$

\section{Manifestasi Klinis dan Diagnosis Banding Vaskulitis Kutan Leukositoklastik}

Lesi primer yang paling sering berupa purpura yang dapat diraba akibat keterlibatan pembuluh darah kecil di kulit. Sering terdapat di ekstremitas bawah, ekstremitas atas, namun lebih jarang di badan bagian atas. Lesi kulit lain yang kemungkinan 
dapat terjadi adalah bula hemoragik, pustul, urtika atau plak anular, dan nodus yang bervariasi kedalamannya dan dapat berkembang menjadi ulkus. Nodus dapat berkaitan dengan livedo retikularis yang menunjukkan bahwa terdapat kerusakan pembuluh darah di dermis bagian bawah dan hipodermis. ${ }^{2,6}$

\section{Pemeriksaan Histopatologi Waktu, Teknik Pengambilan, dan Pemilihan Lesi}

Diagnosis melalui biopsi kulit dipengaruhi oleh kedalaman biopsi. Pada umumnya, biopsi plong dan biopsi eksisi sampai subkutis merupakan pemeriksaan yang penting untuk mendapatkan lesi vaskulitis di seluruh ukuran pembuluh darah. Secara garis besar, biopsi yang diperluas sampai subkutis diambil dari lesi yang paling lunak, kemerahan, atau purpura. Lesi kulit adalah kunci hasil diagnostik yang bermakna. Waktu optimal untuk biopsi kulit adalah 24-48 jam setelah awitan lesi vaskulitis. ${ }^{2,3}$

Biopsi plong dari lesi sampai kedalaman kulit yang tepat, dapat memastikan hampir seluruh sindrom vaskulitis pembuluh darah kecil. Lesi purpura pada 24 jam pertama ditandai dengan deposit fibrin di dalam dinding pembuluh darah disertai dengan infiltrasi neutrofil di dinding pembuluh darah dan dikelilingi ekstravasasi eritrosit dan debris nuklear. Setelah 24 jam, neutrofil mulai digantikan oleh limfosit dan makrofag. Oleh karena itu, biopsi pada lesi lebih dari 48 jam, tanpa memperhatikan bentuk vaskulitis, kemungkinan menunjukkan infiltrat limfosit yang banyak (Gambar 1)., ${ }^{9,10}$
Pada kasus untuk menilai penyebab livedo racemosa, spesimen biopsi yang dalam sampai subkutis sebaiknya diambil dari segmen pusat livedo sirkular (pusat adalah putih, merah adalah perifer), karena disana terdapat pembuluh darah stenosis yang menyebabkan sianotik perifer. Pada kasus tersebut, setiap potongan dari keseluruhan spesimen sering diperlukan untuk menemukan fokus vaskulitis. ${ }^{8,9}$

Spesimen biopsi sebaiknya diambil dari lesi non-ulserasi karena temuan paling sering secara insidental terlihat di dasar ulkus. Jika hanya terdapat ulkus superfisial, disarankan biopsi diambil dari tepi ulkus. Pada kasus ulkus yang dalam atau ulkus "punched out", biopsi subkutis termasuk pusat ulkus akan meningkatkan nilai diagnostik dan mengidentifikasi vaskulitis arterial (misal poliarteratis nodosum atau PAN). ${ }^{9,10}$

Apabila tidak dilakukan biopsi untuk imunofluoresensi direk (IFD) akan membuang kesempatan untuk memperoleh informasi yang berharga, terlebih lagi, penemuan deposit IgA vaskular adalah sine qua non pada Henoch Schonlein purpura (HSP) dan vaskulitis IgA pada dewasa. Hampir sama dengan pewarnaan haematoxylin-eosin (HE), IFD juga berkaitan dengan waktu pengambilan biopsi pada lesi. Pada kasus vaskulitis immune complex-mediated, IFD 100\% akan tampak imunoglobulin dalam 48 jam pertama, $70 \%$ akan positif pada 48-72 jam, dan setelah 72 jam imunoglobulin tidak akan terdeteksi. Meskipun demikian, komplemen masih akan tetap terdeteksi pada $>50 \%$ lesi vaskulitis setelah 72 jam. ${ }^{8-10}$
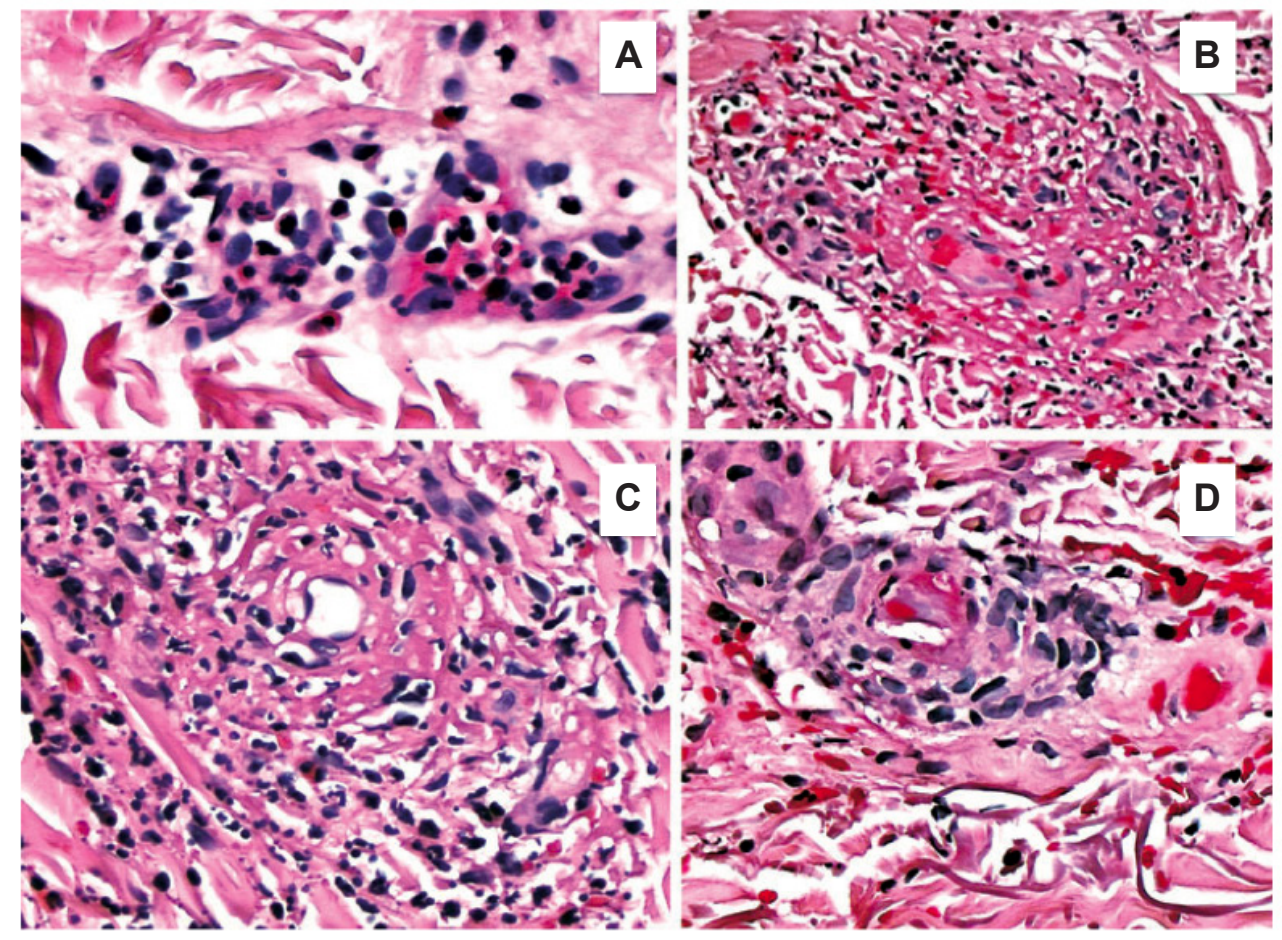

Gambar 1 (A-D). Tahap vaskulitis leukositoklastik kutan 
Temuan histopatologi vaskulitis bergantung pada waktu biopsi. Lesi awal VLK menunjukkan adanya infiltrat neutrofil yang tersebar dan inti debris di sekeliling venul postcapillary (Gambar 1A). Lesi matur VLK menunjukkan fibrin yng bervariasi jumlahnya, nuclear debris disekitar dinding pembuluh darah kecil yang meluruh (Gambar 1B dan C). Lesi tua/pudar VLK memiliki sedikit inti debris dan deposit fibrin di dalam dan sekitar pembuluh darah, lebih banyak infiltrat mononuklear, dan banyak ekstravasasi sel darah merah (Gambar 1D). ${ }^{10}$

\section{Histopatologi vaskulitis leukositoklastik kutan (VLK)}

Diagnosis VLK dapat ditegakkan berdasarkan dua kriteria, yaitu: infiltrat neutrofil perivaskular dengan leukositoklasia dan nekrosis fibrinoid. Nama vaskulitis leukositoklastik digunakan oleh karena ditemukan nukleus-nukleus yang menjadi fragmen (karyorrhexis atau leukositoklastik)., ${ }^{1,2}$ Terdapat kriteria diagnostik vaskulitis kutan secara histopatologi menurut Carslon, yang disajikan pada Tabel 1.,10

Tabel 1. Kriteria Diagnostik Vaskulitis Kutan secara Histopatologi 9,10

\begin{tabular}{l}
\hline Tanda histologi vaskulitis akut (aktif) \\
\hline Pembuluh darah kecil dermis (venula dan arteriol) (memenuhi 2 \\
dari 3 kriteria dengan tanda * yaitu : \\
Infiltrat inflamasi angiosentrik*, \\
- Gangguan dan/atau kerusakan dinding pembuluh darah akibat \\
infiltrat inflamasi* \\
- Deposit fibrin (nekrosis fibrin) pada intramural dan/atau \\
intraluminal* \\
Pembuluh darah muskular subkutan (arteri kecil dan vena): \\
- Infiltrasi dinding pembuluh darah muskular oleh sel inflamasi* \\
- Deposisi fibrin (nekrosis fibrinoid) pada intramural dan/atau \\
intraluminal*
\end{tabular}

Perubahan sekunder vaskulitis aktif (diduga tetapi bukan diagnostik untuk vaskulitis):

- Ekstravasasi sel darah merah (petekiae, purpura, hematoma),

- Nuclear dust, perivaskular (leukositoklasia),

- Endotel bengkak, meluruh atau nekrosis,

- Kelenjar ekrin nekrosis untuk regenerasi dan dapat ditemukan sel basal hiperplasia,

- Ulserasi, Nekrosis/infark.

Sekuel histologi vaskulitis (tanda kronis dan lesi penyembuhan vaskulitis):

- Laminasi (onion-skinning) dinding pembuluh darah,

- Obliterasi luminal (endarteritis obliterans),

- Segmental atau hilang sempurna lamina elastis pada pembuluh darah sedang dan besar berkaitan dengan jaringan parut aseluler*,

- Angioendotheliomatosis reaktif,

- Neovaskularisasi pada adventitia

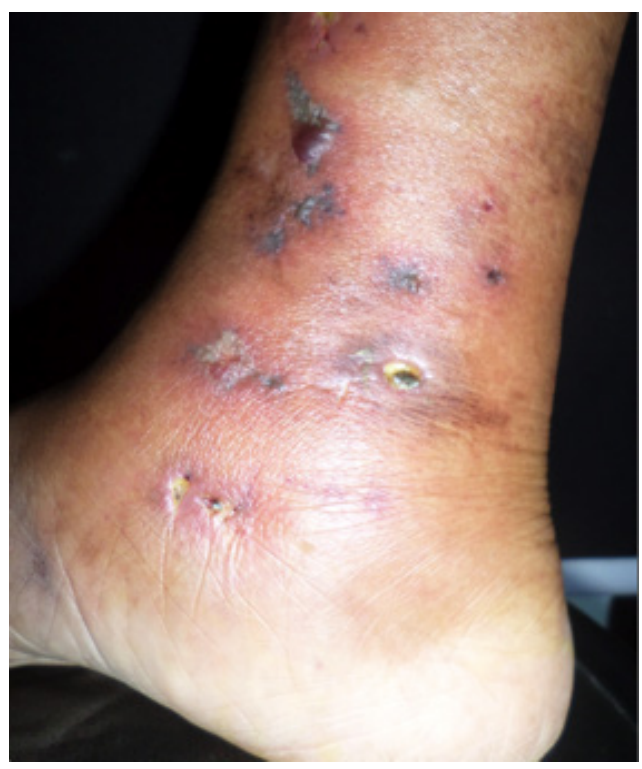

Gambar 2. Vaskulitis leukositoklastik kutan secara klinis berupa plak eritematosa dan bula hemorargik dengan dasar eritematosa, terdapat erosi, ulkus tertutup krusta kecoklatan, edema di sekitar lesi, dan teraba hangat (Foto koleksi Laboratorium Dermatologi dan Venereologi FKUB/RSSA)

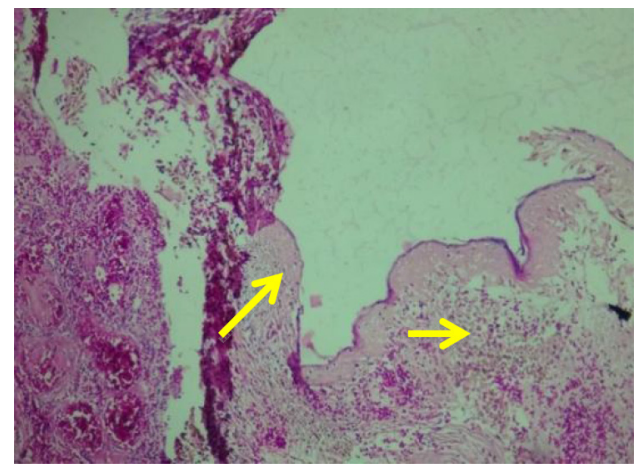

Gambar 3A. Ekstravasasi eritrosit pada epidermis dan dermis (panah kuning), pewarnaan HE, perbesaran 100x (Foto koleksi Laboratorium Patologi Anatomi FKUB/RSSA)

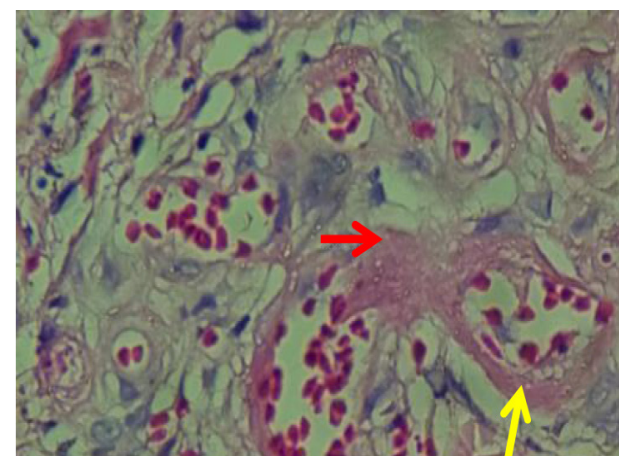

Gambar 3B. Edema pada endotel (panah kuning), nekrosis fibrinoid (panah merah), pewarnaan HE, perbesaran 400x (Foto koleksi Laboratorium Patologi Anatomi FKUB/RSSA) 


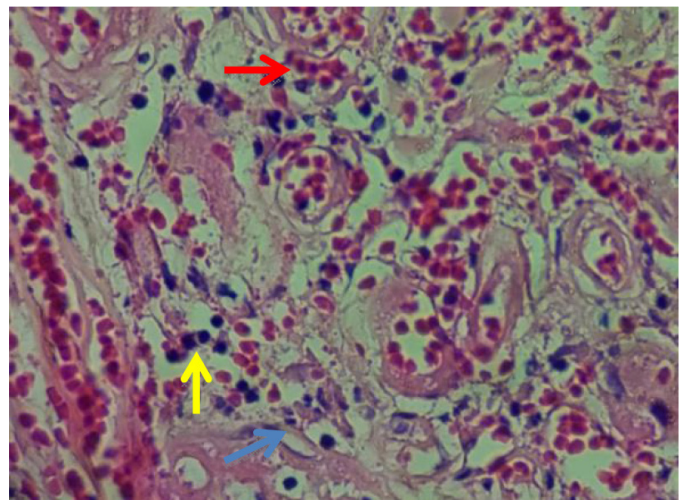

Gambar 3C. Sel radang campuran berupa neutrofil (panah merah) dan limfosit (panah kuning). leukositoklasia (panah biru), pewarnaan HE, perbesaran 400x (Foto koleksi Laboratorium Patologi Anatomi FKUB/RSSA)

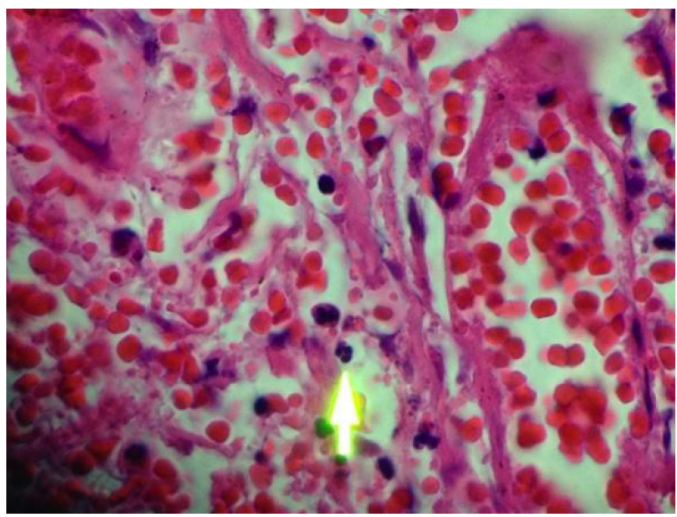

Gambar 3D. Neutrofil perivaskuler (panah kuning) disertai dengan ekstravasasi sel darah merah, pewarnaan HE, perbesaran 1000x (Foto koleksi Laboratorium Patologi Anatomi FKUB/RSSA)

\section{PENUTUP}

Diagnosis vaskulitis merupakan sebuah tantangan Vaskulitis leukositoklastik kutan adalah bentuk vaskulitis kutan yang mengenai pembuluh darah kecil dengan gambaran klinis pada umumnya berupa purpura, ulkus, dan bula disertai gambaran histopatologis berupa reaksi vaskulopatik dengan tanda khas degenerasi apoptotik dari nukleus sel neutrofil (leukositoklasia), nekrosis fibrinoid di dinding pembuluh darah, dan ekstravasasi eritrosit. Spesimen biopsi sebaiknya diambil dari lesi yang paling lunak, eritem atau purpura atau lesi nonulserasi dengan memperhatikan usia lesi yang diambil untuk dipastikan dengan hasil histopatologi. Oleh karena itu, sangat diperlukan korelasi antara manifestasi klinis, teknik biopsi dan gambaran histopatologi untuk memastikan diagnosis vaskulitis leukositoklastik kutan.

\section{DAFTAR PUSTAKA}

1. Pulido-Perez A, Aviles-Izquierdo J.A, Suarez-Fernandez R. Cutaneous vasculitis. Actas Dermosifiliogr. 2012;103(3):179-91.

2. Gota CE, Calabrese LH. Diagnosis and treatment of cutaneous leukocytoclastic vasculitis. Int J Clin Rheumatol. 2013;8(1):4960.

3. Chen KR. Histopathology of Cutaneous Vasculitis. Dalam: Amezcua-Guerra LM, penyunting. Advances in the Diagnosis and Treatment of Vasculitis. Rijeka: InTech; 2011.h.19-56.

4. Shinkai K, Fox L. Cutaneous vasculitis. Dalam: Bolognia J, Jorizzo JL, Schaffer JV, penyunting. Dermatology. Edisi ke-3. London: Elsevier Saunders; 2012.h.385-410.

5. Jordan AC, Mercer SE, Phelps RG. Pathology of the cutaneous vasculitides: a comprehensive review. Dalam: Amezcua-Guerra LM, penyunting. Advances in The Etiology, Pathogenesis and Pathology of Vasculitis. Rijeka: InTech. 2011.h.115-52.

6. Merkel PA, Monach PA. Systemic Necrotizing Arteritis. Dalam: Goldsmith LA, Katz SI, Gilchrest BA, Paller AS, Leffel DJ, Wolff $\mathrm{K}$, penyunting. Fitzpatrick's Dermatology in General Medicine. Edisi ke-8. New York: Mc Graw-Hill Co; 2012.h.2003-27.

7. Barksdale SK, Barnhill RL. Vasculitis and Related Disorder. Dalam Barnhill RL, Crowson AN, Magro CM, Piepkorn MW, penyunting. Dermatopathology. Edisi ke-3. New York: Mc Graw Hill; 2010.1(9):179-209.

8. Haemel A, Fox L, Connoly MK. Cutaneous small-vessel vasculitis. Dalam: Ball GV, Fessler BJ, Bridges SL, penyunting. Oxford textbook of Vasculitis. Edisi ke-3. United Kingdom: Oxford; 2014. h.517-23.

9. Carlson JA, Al-Rohil RN. Cutaneous vasculitis. Dalam: Busam KJ, Goldblum JR, penyunting. Dermatopathology. Edisi ke-2. Philadelphia: Elsevier Saunders; 2016.h.181-8.

10. Carlson JA. Histological assessment of cutaneous vasculitis. Histopathology. 2010;56:3-23. 